Dept. of Poultry Diseases,

Faculty of Veterinary Medicine, Al Baath University, Syria.

\title{
INVESTIGATION OF THREE E.COLI SEROGROUPS (APEC) ISOLATED FROM FERTILE EGGS OF COMMERCIAL CHICKEN IN THE SOUTHERN REGION OF SYRIA
}

(With 6 Tables)

By

NOUR ALI ALBURAKI and M. ALI ALIMADI

(Received at 15/11/2011)

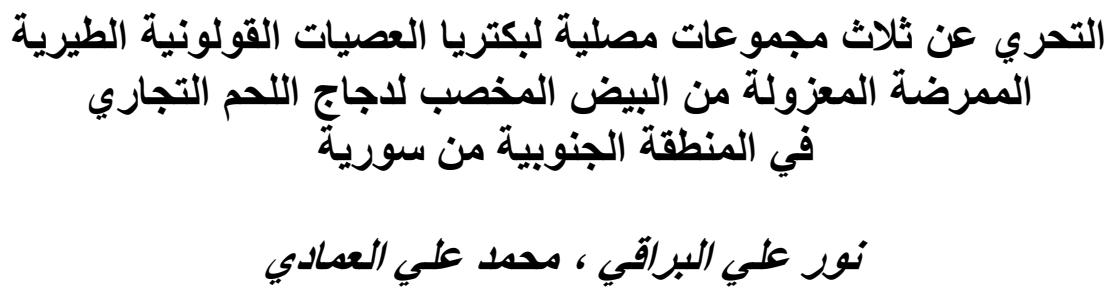

تم عزل بكتريا العصيات القولونية من 200 عينة بيض معد للفقس (مخصب) بعمر يوم واحد

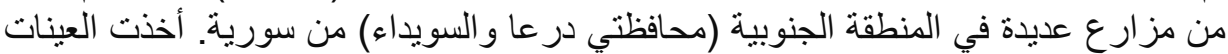

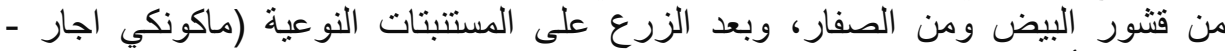

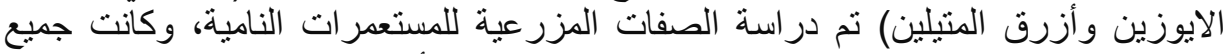

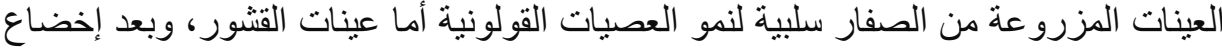

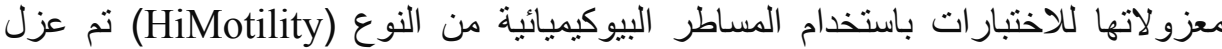
العصبات القولونية بنسبة 94 \% في منطقة در عا وبنسبة 92 \%

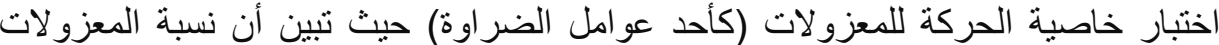

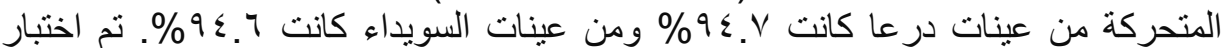

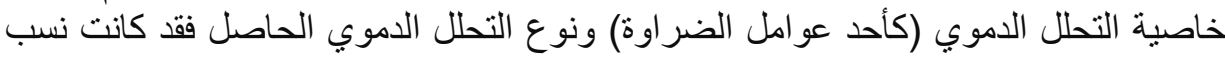

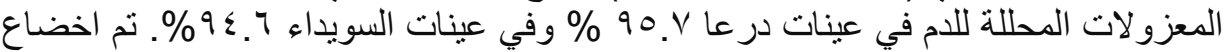

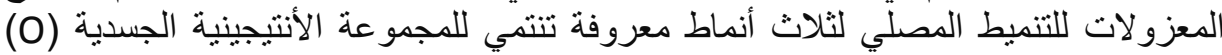

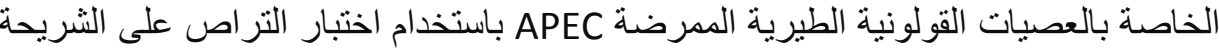

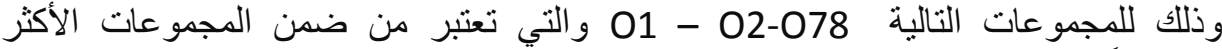
امر اضيةً وشيو عاً في مزارع الدجاج وقد وجدت الأنماط الثلاثة المختبرة

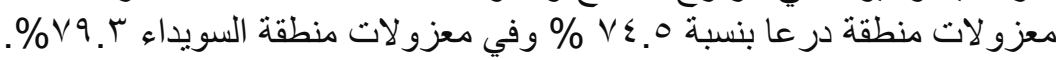

\section{SUMMARY}


E.coli bacteria has been isolated from a total of two hundred one day old fertile eggs of commercial meat type chicken from poultry farms in the southern region of Syria (Daraa and Souweida) by taking samples from the eggshells and yolks. Eggs were not subjected to cleaning and sterilization. So, we obtained 94\% isolates from Daraa eggshell samples and $92 \%$ isolates from Souweida but all yolk samples were found free of E.coli bacteria. The motility of all isolates as one of the virulence factors were tested and found that $94.6 \%$ from Souweida isolates and $94.7 \%$ from Daraa isolates were motile. The hemolysis, as another virulence factor, was tested in all isolates and we found that $94.6 \%$ of Souweida isolates were hemolytic and $76.1 \%$ of them were type beta (entirely hemolytic), but in Daraa $95.7 \%$ of the isolates were hemolytic and $72.3 \%$ of them were type beta. Isolates were serotyped by agglutination test with a specific antisera of somatic antigen to the three serogroups $\mathrm{O} 1, \mathrm{O} 2$ and $\mathrm{O} 78$ which are considered from the most prevalent and pathogenic serogroups in poultry farms. A percentage of $74.5 \%$ and $79.3 \%$ from the isolates of Daraa and Souweida, respectively were belonged to the three tested serogroups.

Key words: Escherichia coli, Pathogenic, Serotyping.

\section{INTRODUCTION}

Escherichia coli, which is a part of the normal microbiota of birds (Bettelheim, 1994) in intestinal and respiratory tracts (Morris and Sojka, 1985), was forgotten as a potential pathogen. However, lesions in which E.coli is the primary and often the secondary agent cause economic damage due to lower corporal development, insufficient feed conversion, increasing mortality, higher cost with medicine, and condemnation of carcasses (Rocha et al., 2008).

Avian colibacillosis is responsible for large economic losses in poultry rearing resulting in low performances, weight loss, onset of egg production and mortality. Avian pathogenic (APEC) Escherichia coli, the causative bacteria of colibacillosis induces various syndromes including Yolk Sac Infection, respiratory tract infection (Airsacculitis), Acute Colisepticemia, Salpingitis and Cellulitis, the most common forms of colibacillosis occurs among 2 to 10 week-old chickens (Aggad et al., 2006). 
However, Yolk sac infection (YSI) is a major cause of mortality of chicks during the first week post-hatching and it is an economically important disease since it increases mortality of 8 days old and causes poor weight gain. In addition, birds that survive to a YSI outbreak show poor carcass quality (Cortes et al., 2004).

Several authors had reported earlier that contamination of fertile eggs in the nest at the broiler breeder farm is the main cause of YSI (Gordon and gordan, 1985; Mosqueda and Lucio, 1985; Rojo, 1987).

The rate of infection with E.coli bacteria (colibacillosis) is approximately $30-40 \%$ of the other diseases (Cheville and Arp, 1998).

It is worth to mention that some E.coli strains seem to be more aggressive than others and some serogroups (O1,O2 and O78) are more frequently associated with septicemic clinical cases (Barbour et al., 1970; Cheville and Arp, 1998).

The result of hemolysis tests showed that hemolytic activities of APEC isolates correlated to the virulence of avian colibacillosis. In addition, approximately $90 \%$ of the isolates, which showed the hemolysis, harbored one or more virulence genes (Moon et al., 2006).

The flagella, which are thin surface appendices, give motility to Gram positive and negative bacteria in aqueous media. Their rotating movements allow microorganisms to approach adjacent epithelial cells, crossing the mucus barrier and causing adhesion, multiplication, colonization and infection.

This study aims to investigate the three frequently strains from $\mathrm{O}$ serogroups (O1,O2 and $\mathrm{O} 78)$ and to test the motility and hemolysis characteristics virulence factors.

\section{MATERIALS and METHODS}

\section{Samples Collection}

During the period from may 2010 to April 2011, a total of two hundred one-day-old fertile eggs of meat type chicken were collected from poultry farms in the southern region of Syria (Dara and Souweida).

Eggs were not subjected to cleaning and sterilization and transported to the laboratory after being wrapped with sterile tin foils.

\section{Samples Preparation:}


Upon reaching the laboratory, samples were taken from the surface of eggs by swabs (HiMedia Laboratories Pvt. Limited, India) and incubated in nutrient broth (HiMedia Laboratories Pvt. Limited, India) overnight at $37^{\circ} \mathrm{C}$.

Eggs were cleaned and sterilized then samples of yolk were taken and incubated in nutrient broth at $37^{\circ} \mathrm{C}$ for 48 hours.

\section{Cultural and Biochemical Characterization:}

The samples were cultured, using a sterilized loop, on specific solid media (MacConkey - EMB agar (OXOID)) and incubated at $37^{\circ} \mathrm{C}$ for 24 hours.

All bacterial colonies were selected from each sample. These colonies were isolated in pure culture for further identification.

A cultural suspension with $5 \mathrm{ml}$ of physiological saline was prepared from each isolate and compared with Mcfarland standard to have a right turbidity. This material was used to inoculate HiMotality Biochemical Kit for E.coli (HiMedia Laboratories Pvt. Limited, India) wich include the folwing test; Motility, Indole, Citrate, Glocoronidase, Nitrate, ONPG, Lysine, Lactose, Glucose, Sucrose and Sorbitol.

Kits were inoculated, incubated, handled, and analyzed according to the manufacturer's instructions.

\section{Motility test:}

The primary Hanging Drop Method as described by Cowan (1985) was carried out to detect the motility of all isolates. Isolates which didn't show motility had been retested by using SIM agar and incubated at $37^{\circ} \mathrm{C}$ for 24 hours (Quinn et al., 1994). In addition, results were supported with Biochemical kits which include a motility test.

\section{Hemolytic Test:}

The hemolysis of isolates was tested by culturing on blood agar and incubated $24 \mathrm{~h}$ at $37^{\circ} \mathrm{C}$. The isolates which showed a complete hemolysis on the blood agar had the letter "Beta", for the partial hemolysis "Alpha" and for the negative results " Gamma" (Quinn et al., 1994).

\section{Serotyping:}

Isolates were serotyped by agglutination test with a specific antisera (Veterinary Institute et al., 2009) of three different Somatic O antigens (O1,O2 and $\mathrm{O} 78)$.

\section{RESULTS}


All yolk samples collected from the two regions (Daraa and Souweida) were found free from E.coli bacteria.

Eggshell samples had been cultured on MacConkey agar and all colonies were primary classified as E.coli based on the colonial characteristics (Table 1).

Table 1: Culture characteristics on MacConkey Agar

\begin{tabular}{|l|c|c|}
\hline & Daraa & Souweida \\
\hline $\begin{array}{l}\text { Pink colonies-Lactose } \\
\text { fermentation }\end{array}$ & $100 \%$ & $100 \%$ \\
\hline
\end{tabular}

94\% of Daraa eggshell samples and $92 \%$ of Souweida's were E.coli isolates according to the results of Biochemical tests (using Bio. Kits) which had been applied on the two hundred samples (Table 2).

Table 2: E.coli isolates after Biochemical tests (HiMotility Kits)

\begin{tabular}{|l|c|c|}
\hline & Daraa & Souweida \\
\hline $\begin{array}{l}\text { E.coli } \text { isolates after } \\
\text { Biochemical tests } \\
\text { (HiMotility Kits) }\end{array}$ & $94 \%$ & $92 \%$ \\
\hline
\end{tabular}

$94.7 \%$ of Daraa isolates and $94.6 \%$ of Souweida were motile (Table 3 ).

Table 3: E.coli motility.

\begin{tabular}{|l|c|c|}
\hline $\begin{array}{l}\text { Percentage of E .coli } \\
\text { isolates motile }\end{array}$ & Daraa & Souweida \\
\cline { 2 - 3 } & $94.7 \%$ & $94.6 \%$ \\
\hline
\end{tabular}

$95.7 \%$ of Daraa isolates were hemolytic and $72.3 \%$ of them were type beta. $94.6 \%$ of Souweida isolates were hemolytic and $76.1 \%$ of them were type beta (Table 4).

Table 4: Hemolysis on blood agar. 


\begin{tabular}{|l|c|c|}
\hline & Daraa & Souweida \\
\hline $\begin{array}{l}\text { hemolytic E.coli } \\
\text { isolates }\end{array}$ & $95.7 \%$ & $94.6 \%$ \\
\hline Beta hemolysis\% & 72.3 & 76.1 \\
\hline Alpha hemolysis \% & 23.4 & 18.5 \\
\hline Gamma hemolysis\% & 4.3 & 4,5 \\
\hline
\end{tabular}

$94.7 \%$ of Daraa's isolates and $94.6 \%$ of Souweida's were motile and hemolytic at the same time.

Only 4 isolates from Daraa and 5 isolates from Souweida were motile and non-hemolytic.

Only 5 isolates from Daraa and 5 isolates from Souweida were hemolytic and non-motile (Table 5).

Table 5: Motility and hemolysis

\begin{tabular}{|l|c|c|}
\hline & Daraa & Souweida \\
\hline motile \& hemolytic n (\%) & $85 / 94(90.43)$ & $82 / 92(89.13)$ \\
\hline motile \& not hemolytic n & 4 & 5 \\
\hline not motile \& hemolytic n & 5 & 5 \\
\hline
\end{tabular}

The three serogroups $(\mathrm{O} 1, \mathrm{O} 2$ and $\mathrm{O} 78)$ formed a percentage of 74.5 in Daraa isolates and 79.3 in Souweida' s.

The percentage of $\mathrm{O} 1$ was 7.4 and 7.6 in Daraa and Souweida respectively.

The percentage of O2 was 21.3 and 19.6 in Daraa and Souweida respectively, while the percentage of O78 was 45.7 and 52.2 in Daraa and Souweida respectively (Table 6).

Table 6: Serotypes percentages

\begin{tabular}{|l|c|c|c|c|}
\hline Serotypes & $(\mathrm{O} 1+\mathrm{O} 2+\mathrm{O} 78)$ & $\mathrm{O} 1$ & $\mathrm{O} 2$ & $\mathrm{O} 78$ \\
\hline Daraa (\%) & 74.5 & 7.4 & 21.3 & 45.7 \\
\hline $\begin{array}{l}\text { Souweida } \\
(\%)\end{array}$ & 79.3 & 7.6 & 19.6 & 52.2 \\
\hline
\end{tabular}

\section{DISCUSSION}


In this study the isolation trials resulted in detaining of 94 and 92 E.coli isolates (of 200 samples) from Daraa and Souweida eggshells, respectively. All strains isolated were found in the eggshell which means that they had not crossed the eggshell barrier.

In a recent study authors had 16 E.coli strains isolated at 19 days of incubation obtained from inside the egg and 12 from the eggshell. Additionally, from the Yolk sac of 21 days (embryos) they found 18 E.coli strains of 47 isolates and 86 E.coli of 188 isolates from yolk sac of dead chicks (Cortes et al., 2004).

According to a recent study in Mexico they obtained 50\% of E.coli isolated from fertile eggs (Rojo, 1987).

A percentage of 94.7 of Daraa isolates and 94.6 of Souweida isolates were motile, these percentages show a high level comparing with the results of other study.

In a recent study (Rocha et al., 2008), motility was detected in $54.1 \%$ of the samples and higher than $36.8 \%$ that had been reported by McPeake et al. (2005).

By testing the hemolysis of all isolates we found that the percentage of hemolysis for the two region's isolates were approximately close even the percentage of hemolysis type, for example; $95.7 \%$ of Daraa isolates was hemolytic and that was $94.6 \%$ for Souweida isolates.

The Beta hemolysis for Daraa isolates was $72.3 \%$ and for Souweida isolates it was $76.1 \%$.

And according to a recent study in Korea (Moon et al., 2006), it was found that $72 \%$ (48 isolates) of the APEC- isolated from birds with colibacillosis- revealed $\alpha$ or $\beta$ hemolysis on blood agar plates. In addition, approximately $90 \%$ of the isolates, which showed the hemolysis, harbored one or more virulence genes (Moon et al., 2006), that can give a reasonable idea about the relationship between hemolysis characteristic and pathogenicity of strains.

A relationship between the two characteristics; motility and hemolysis was observed as $90.4 \%$ of Daraa isolates and $89.1 \%$ of Souweida isolates were found motile and hemolytic.

On the other hand, only 4 isolates from Daraa and 5 isolates from Souweida were found motile and non-hemolytic, while 5 isolates from Daraa and 5 isolates from Souweida were found hemolytic and nonmotile. 
In conclusion, the majority of the motile isolates ( 85 isolates/94 for Daraa and 82 isolates/92 for Souweida) were carrying the hemolytic characteristic and showed a Beta or Alpha hemolysis on blood agar.

The results showed that the three serogroups exist in the two regions with percentages of 74.5 and 79.3 in Daraa and Souweida's samples, respectively which indicated that the two percentages were high and approximately equal.

In addition, there was no significant differences in comparing each serogroups percentage in both regions.

In Algeria, a study showed that $82 \%$ of E.coli strains isolated from chickens with colibacillosis belonged to the three serogroups (O1, O2 and 078 ) as 9\%, 29\% and 44\%, respectively (Aggad et al., 2006).

This study was repeated in the same area after 4 years in which it was found that $48 \%$ of the isolates belonged to the three serogroups (O1, $\mathrm{O} 2$ and $\mathrm{O} 78$ ) as 15\%, 16\% and 21\%, respectively (Aggad et al., 2010). These results agree with the results of a study in Germany. They had grouped $49.6 \%$ of E.coli strains isolated from colisepticemic poultry to the three serogroups (O1, O2 and O78) (Ewers et al., 2004).

Other study in UK showed that the O78 serogroups represented $55 \%$ and $27 \%$ of broilers and layers colisepticemic isolates, respectively (McPeake et al., 2005).

The present study indicated that the 078 serogroups exist in broilers more than in layers. There are a few researches about isolation of $\mathrm{O}$ serogroups from the fertile eggs, according to a study they found that the E.coli bacteria increased rapidly by number during the period between eggs production and post-hatching (Cortes et al., 2004).

In conclusion, utilization of Biochemical Kits for detecting the characteristics of E.coli strains is more suitable and easier than using the standard techniques. It gives accurate results and save time although it is more expensive.

It is remarkable that the three serogroups $(\mathrm{O} 1, \mathrm{O} 2$ and $\mathrm{O} 78)$ were existed in southern region of Syria with a high percentage and this isolates were holding pathogenic characteristics like hemolysis and motility. These results confirms the results of other research that these three serogroups are - even in Syria- considered from the most prevalent and pathogenic serogroups.

A more detailed study is needed in order to determine the relationship between different strains isolated in the southern and in other regions of Syria and to establish the pathogenic characteristics possessed by those strains. Ultimately, identification of potential 
virulence traits may allow for their use as specific markers for the diagnosis of pathogenic strains.

\section{REFERENCES}

Bettelheim, K.A. (1994): Biochemical characteristics of Escherichia coli, p.3-30. In: Gyles C.L. (ed.), Escherichia coli in Domestic Animals and Humans. CAB International, Wallington, Oxon, $\mathrm{UK}$.

Morris, J.A. and Sojka, W.J. (1985): The virulence of Escherichia coli, p.47- 77. In: Sussman M. (ed.), Escherichia coli as a Pathogen in Animals. Academic Press, London.

Rocha, A.C.G.P.; Rocha, S.L.S.; Lima-Rosa, C.A.V.; Souza, G.F.; Moraes, H.L.S.; Salle, F.O.; Moraes, L.B. and Salle, C.T.P. (2008): Genes associated with pathogenicity of avian Escherichia coli (APEC) isolated from respiratory cases of poultry, Brazil. 28(3): 183-186.

Aggad, H.; Ammar, A.; Hammoudi, A. and Kihal, M. (2006): Antibioresistance of E.coli strains isolated from chicken colibacillosis in western Algeria. (123-126.)

Cortes, C.R.; Isaias, G.T.; Cuello, C.L.; Flores, J.M.V.; Anderson, R.C. and Campos, C.E. (2004): Bacterial isolation rate from fertile eggs, hatching eggs and neonatal broilers with yolk sac infection. Mexico, pp. 12-16.

Gordon, R.F. and Jordan, F.T.W. (1985): Enfermedades de las aves 2a edición. El Manual Moderno. pp. 54-56. México, D.F., México.

Mosqueda, T.A. and Lucio, M.B. (1985): Enfermedades comunes de las aves domésticas. Universidad Nacional Autónoma de México. pp. 377-381. México, D.F., México.

Rojo, M.E. (1987): Enfermedades de las aves. 2a. Edición. Editorial Trillas. pp. 213-215. México, D.F., México

Cheville, N.F and Arp, L.H. (1998): Comparative pathologic findings of Escherichia coli infection in birds. Journal of American Veterinary Medical Association., 137: 27-31 .

Barbour, SD.; Nagaishi, H.; Templin, A. and Clark, AJ. (1970): Biochemical and genetic studies of recombination proficiency in Escherichia coli. II. Rec+ revertants caused by indirect suppression of rec- mutations. Proc Natl Acad Sci U S A. 67(1): 128-135. 
Moon, B.M.; Won, G.Y.; Choi, Y.Y.; Jin, J.K.; Oh, I.G.; Park, J.H.; Eo, S.K. and Lee, J.H. (2006): Isolation and characteristics of avian pathogenic Escherichia coli from birds associated with colibacillosis, Korea, p(61).

Cowan, ST. (1985): Biochemical behavior of E. coli. Journal of General Microbiology 8: 391.

Quinn, P.J.; Carter, M.E.; Markey, B. and Carter, G.R. and Taj Dolatshani, F. (1994): Clinical veterinary microbiology, pp: 209-236.

Veterinary Institute, University of Constantine, Algeria (2009): Airborne bacterial contamination in tow broilers in North-East of Algeria, Veterinary World Vol. 2 (2); p49-50.

McPeake, S.J.W.; Smyth, J.A. and Ball, H.J. (2005): Characterization of avian pathogenic Escherichia coli (APEC) associated with Colisepticaemia compared to faecal isolates from healthy birds. Northern Ireland, UK. 110(3-4): 245-253.

Aggad, H.; Ammar, A.; Hammoudi, A. and Kihal, M. (2010): Antimicrobial resistance of Escherichia coli isolated from chickens with colibacillosis Algeria (3): 303-306.

Ewers, C.; Janben, T.; Kiebling, S.; Philipp, H.C. and Wieler, L.H. Molecular epidemiology of avian pathogenic Escherichia coli (APEC) isolated from Colisepticemia in poultry. Germany, 104(1-2):91-101. 